Volume 4 Nomor 1, Februari 2019, halaman 21-32

\title{
PERBANDINGAN HASIL BELAJAR MATEMATIKA ANTARA SISWA YANG PEMBELAJARANNYA MENGGUNAKAN MODEL GIVING QUESTION AND GETTING ANSWER DENGAN STUDENT TEAMS ACHIEVEMENT DIVISION
}

\section{COMPARISON OF MATHEMATICAL LEARNING RESULTS BETWEEN STUDENTS WHO LEARNED USING GIVING QUESTION AND GETTING ANSWER MODEL WITH STUDENT TEAMS ACHIEVEMENT DIVISION}

\author{
Eryanti $^{1}$, Nandang $^{2}$, Denni Ismunandar ${ }^{3}$ \\ ${ }^{1}$ SMK N 1 Losarang, Jln. Raya Pantura Losarang, Desa Santing, Indramayu, \\ eryantiyucan@gmail.com \\ ${ }^{2,3}$ Universitas Wiralodra, Jln. Ir. H. Djuanda Km3 Singaraja Indramayu 45213, \\ Nndg1967@yahoo.com,denni.ismunandar@unwir.ac.id
}

\begin{abstract}
ABSTRAK
Penelitian ini bertujuan untuk mengetahui hasil belajar matematika siswa yang lebih baik antara yang menggunakan model pembelajaran Giving Question and Getting Answer dengan Student Teams Achievement Division. Penelitian ini adalah penelitian kuantitatif menggunakan metode eksperimen. Populasi dalam penelitian ini adalah seluruh hasil belajar matematika siswa kelas VII SMP Negeri 1 Lelea Tahun Ajaran 2017/2018. Sampel penelitian diambil dengan menggunakan teknik cluster random sampling. Karena kedua sampel dari kedua kelas eksperimen berdistribusi normal dan homogen, maka uji hipotesis menggunakan uji-t. Berdasarkan hasil disimpulkan bahwa hasil belajar matematika siswa yang menggunakan model pembelajaran Giving Question and Getting Answer lebih baik daripada Student Teams Achievement Division.

Kata Kunci: Hasil Belajar Matematika, Giving Question and Getting Answer, Student Teams Achievement Division
\end{abstract}

\begin{abstract}
This aims of the study is to find out better student learning outcomes between those who use the Giving Question and Getting Answer learning model and the Student Teams Achievement Division model. This research is quantitative research using experimental method. The population in this study were all mathematics learning outcomes of class VII students of SMP Negeri 1 Lelea 2017/2018 Academic Year. The research sample was taken using cluster random sampling technique. Because both samples from the two experimental classes are normally distributed and homogeneous, the hypothesis test uses the t-test. Based on the results of the study, it can be concluded that the mathematics learning outcomes of students who use the Giving Question and Getting Answer learning model are better than the Student Teams Achievement Division.
\end{abstract}

Keywords: Mathematics Learning Results, Giving Question and Getting Answers, Student Teams Achievement Division 
Perbandingan Hasil Belajar Matematika Antara Siswa yang Pembelajarannya Menggunakan Model Giving Question And Getting Answer dengan Student Teams Achievement Division

How to Cite: Eryanti, Nandang, \& Ismunandar, D. (2019). Perbandingan Hasil Belajar Matematika Antara Siswa yang Pembelajarannya Menggunakan Model Giving Question And Getting Answer dengan Student Teams Achievement Division. Mathline: Jurnal Matematika dan Pendidikan Matematika, Vol.4, No.1, 21-32.

\section{PENDAHULUAN}

Pendidikan merupakan salah satu aspek penting dalam kehidupan manusia. Dengan adanya pendidikan manusia dapat menumbuh kembangkan potensi-potensi yang ada pada dirinya. Pada dasarnya pendidikan lebih menekankan pada pembentukan serta penanaman sikap dan nilai-nilai. Hamdani (2011) menyatakan bahwa pendidikan bukan sekedar memberikan pengetahuan nilai-nilai atau melatih ketrampilan, pendidikan berfungsi mengembangkan apa yang secara potensial dimiliki peserta didik. Hal ini tertuang dalam UU RI No. 20 Tahun 2003 tentang Sistem Pendidikan Nasional, yaitu pendidikan adalah usaha sadar dan terencana untuk mewujudkan suasana belajar dan proses pembelajaran agar peserta didik secara aktif mengembangkan potensi dirinya untuk memiliki kekuatan spiritual keagamaan, pengendalian diri, kepribadian, kecerdasan, akhlak mulia, serta ketrampilan yang diperlukan dirinya, masyarakat, bangsa dan negara.

Sekolah sebagai salah satu wadah pendidikan selain dalam lingkungan keluarga dan lingkungan organisasi diluar sekolah. Menurut Sudjana (2011), di lingkungan pendidikan sekolah adalah tanggung jawab guru mengarahkan keaktifan siswa melalui pendidikan dalam berbagai bidang studi, agar tercapainya tujuan. Rusman (2013) mengatakan bahwa belajar pada hakikatnya adalah proses interaksi terhadap semua situasi yang ada disekitar individu. Selain itu Harold Spers (Suprijono, 2015) mengungkapkan bahwa belajar adalah mengamati, membaca, meniru, memcoba sesuatu, mendengar dan mengikuti arah tertentu. Proses belajar terjadi karena adanya interaksi seseorang dengan lingkungannya. Oleh karena itu, belajar dapat dilakukan kapan dan dimana saja. Dimyati \& Mudjiono (2006) berpendapat bahwa siswa adalah subjek yang terlibat dalam kegiatan belajar mengajar di sekolah. Dalam pembelajaran di sekolah siswa mengalami suatu proses belajar. Dalam proses tersebut, siswa menggunakan kemampuan mentalnya untuk mempelajari bahan pelajaran.

Salah satu mata pelajaran ada di sekolah adalah pelajaran matematika. Matematika merupakan pelajaran yang wajib diajarkan pada semua jenjang pendidikan, baik sekolah dasar, sekolah menengah maupun perguruan tinggi. Hal ini karena peranan matematika yang sangat penting dalam kehidupan sehari-hari. Uno (2009) menyatakan 
matematika adalah sebagai suatu bidang ilmu yang merupakan alat pikir, berkomunikasi, alat untuk memecahkan berbagai persoalan praktis, yang unsur-unsurnya logika dan intuisi, analisi dan kontruksi, generalitas dan individualitas, dan mempunyai cabangcabang antara lain aritmatika, aljabar, geometri dan analisi.

Jannah (2011) menyatakan matematika adalah ilmu yang paling menjadi momok menakutkan bagi siswa". Siswa beranggapan bahwa pelajaran matematika itu sulit untuk dipahami, sehingga pelajaran matematika kurang diminati oleh siswa. Kesan yang seperti itu mengakibatkan hasil belajar matematika siswa menjadi rendah. Hasil belajar matematika siswa yang rendah tentunya dipengaruhi oleh beberapa faktor, baik yang berasal dari dalam diri siswa itu sendiri (intern) maupun yang berasal dari luar diri siswa (ekstern). Ruseffendi (2006) menyatakan setiap pembelajaran menyangkut siswa yaitu manusia yang belajar dan faktor-faktor yang mempengaruhi dari luar, yaitu: model penyajian materi pelajaran, pribadi dan sikap guru, suasana pengajaran, kemampuan (kompetensi) guru, serta kondisi masyarakat luas.

Salah satu faktor penting yang mempengaruhi proses pembelajaran yang telah disebutkan di atas adalah model penyajian materi. Hal ini berhubungan dengan keterampilan seorang guru bagaimana menyajikan materi pelajaran, supaya dapat ditangkap dengan baik oleh siswanya dan dapat merangsang siswanya untuk terlibat aktif dalam kegiatan pembelajaran. Untuk itu, seorang guru harus memperhatikan faktor-faktor penting yang mendukung tujuan tersebut.

Menurut Heriawan, dkk., (2012), siswa akan belajar dengan baik apabila mereka terlibat secara aktif dalam segala kegiatan dikelas dan berkesempatan untuk menemukan sendiri. Oleh karena itu, dalam melaksanakan kegiatan proses belajar diperlukan model pembelajaran yang tepat. Rohman \& Amri (2013) mengatakan bahwa makin tepat model yang digunakan oleh guru dalam mengajar maka akan semakin efektif dalam kegiatan pembelajaran. Salah satu alternatif yang dapat digunakan adalah model pembelajaran kooperatif.

Model pembelajaran kooperatif banyak digunakan dan diajarkan untuk para pendidik. Karena dengan pembelajaran kooperatif siswa berpartisipasi dan berinteraksi dengan teman dan kelompoknya. Menurut Slavin (Rusman, 2013) bahwa pembelajaran kooperatif mengharuskan siswa berinteraksi secara aktif dan positif dalam kelompok. Menggunakan model pembelajaran yang baik merupakan salah satu solusi untuk meningkatkan hasil belajar matematika siswa, dalam hal ini model pembelajaran berkelompok. Model pembelajaran berkelompok yang aktif terdiri dari beberapa tipe, 
Perbandingan Hasil Belajar Matematika Antara Siswa yang Pembelajarannya Menggunakan Model Giving Question And Getting Answer dengan Student Teams Achievement Division

diantaranya yaitu model pembelajaran Giving Question and Getting Answer dan Student Teams Achievement Division. Model pembelajaran Giving Question and Getting Answer dikembangkan untuk melatih peserta didik memiliki kemampuan dan ketrampilan bertanya dan menjawab pertanyaan. Dengan arti lain, Giving Question and Getting Answer merupakan modifikasi dari model tanya jawab yang merupakan kolaborasi dengan menggunakan potongan-potongan kertas sebagai medianya (Suprijono, 2015).

Model pembelajaran Student Teams Achievement Division merupakan salah satu model pembelajaran kooperatf yang didalamnya beberapa kelompok kecil siswa dengan level kemampuan siswa yang berbeda-beda saling bekerja sama untuk menyelesaikan tujuan pembelajaran (Huda, 2013). Kedua model ini, Giving Question and Getting Answer dan Student Teams Achievement Division merupakan model pembelajaran yang membantu peserta didik untuk memperoleh pengetahuan, ketrampilan, daya pikir dan sikap secara aktif. Menurut Suprijono (2015), "Model pembelajaran adalah suatu perencanaan atau pola yang digunakan sebagai pedoman dalam merencanakan pembelajaran di kelas maupun tutorial ". Menurut Slavin (Heriawan, dkk., 2012), pembelajaran kooperatif merupakan model pembelajaran bagi siswa dalam kelompok yang memiliki kemampuan heterogen.

Berdasarkan uraian di atas, dapat disimpulkan bahwa model pembelajaran kooperatif adalah rencana atau pola yang digunakan sebagai pedoman dalam merencanakan pembelajaran yang inovatif dengan keterlibatan siswa belajar di dalam kelompok yang dipimpin atau diarahkan oleh guru yang dirancang untuk mencapai tujuan pembelajaran. Giving Question and Getting Answer merupakan salah satu model pembelajaran kooperatif. Menurut Suprijono (2015) bahwa model Giving Question and Getting Answer dikembangkan untuk melatih peserta didik memiliki kemampuan dan keterampilan bertanya dan menjawab pertanyaan. Dengan arti lain, model Giving Question and Getting Answer merupakan modifikasi dari model tanya jawab yang merupakan kolaborasi dengan menggunakan potongan-potongan kertas sebagai medianya.

Suprijono (2009) menyatakan langkah-langkah model Giving Question and Getting Answer sebagai berikut. (1) Membagikan dua potongan kartu kepada peserta didik. (2) Mintalah kepada peserta didik menuliskan di kartu itu (a) kartu menjawab, (b) kartu bertanya. (3) Mulai pembelajaran dengan pertanyaan. Pertanyaan bisa berasal dari peserta didik maupun guru. Jika pertanyaan berasal dari peserta didik, maka peserta didik ini diminta menyerahkan kartu yang bertuliskan "kartu bertanya". (4) Setelah pertanyaan diajukan, mintalah kepada peserta didik memberi jawaban. Setiap peserta didik yang 
hendak menjawab diwajibkan menyerahkan kartu yang bertuliskan "kartu menjawab".

Jika sampai akhir sesi ada peserta didik yang masih memiliki 2 potongan kartu atau salah satu dari potongan kartu tersebut, maka mereka diminta membuat resume atas proses tanya jawab yang sudah berlangsung. Tujuan penggunaan model Giving Question and Getting Answer antara lain. (1) Mengecek pemahaman para siswa sebagai dasar perbaikan proses pembelajaran. (2) Membimbing usaha para siswa untuk memperoleh suatu keterampilan kognitif maupun sosial. (3) Memberikan rasa senang pada diri siswa. (4) Merangsang dan meningkatkan kemampuan berpikir siswa. (5) Memotivasi siswa agar terlibat dalam interaksi. (6) Melatih kemampuan mengutarakan pendapat. (7) Mencapai tujuan belajar.

Kelebihan penerapan model Giving Questions and Getting Answer adalah. (1) Suasana lebih menjadi aktif. (2) Anak mendapat kesempatan baik secara individu maupun kelompok untuk menanyakan hal-hal yang belum dimengerti. (3) Guru dapat mengetahui penguasaan anak terhadap materi yang disampaikan. (4) Mendorong anak untuk berani mengajukan pendapatnya. Sedangkan kelemahan penerapan model Giving Questions and Getting Answer adalah (1) pertanyaan pada hakekatnya sifatnya hanya hafalan; (2) proses tanya jawab yang berlangsung secara terus menerus akan menyimpang dari pokok bahasan yang sedang dipelajari; (3) guru tidak mengetahui secara pasti apakah anak yang tidak mengajukan pertanyaan ataupun menjawab telah memahami dan menguasai materi yang telah diberikan.

Dalam penelitian ini, model pembelajaran adalah model pembelajaran Giving Questions and Getting Answer dimana guru membentuk kelompok yang heterogen. Siswa dalam satu kelompok diminta untuk menulis sebuah pertanyaan di kartu pertanyaan dan menulis sebuah kesanggupan untuk menjelaskan materi tertentu di kartu penjelasan. Jika pertanyaan yang ditulis sama dengan pernyataan kesanggupan di kartu penjelasan, maka perwakilan dari kelompok diminta untuk menjelaskan materi tersebut. Model pembelajaran lain yang dilaksanakan dalam pembelajaran ini adalah model pembelajaran kooperatif tipe Student Team Achievement Division.

Model pembelajaran kooperatif tipe Student Team Achievement Divisions merupakan pembelajaran kooperatif yang paling tua dan paling banyak diteliti (Slavin, 2005). Student Team Achievement Division merupakan salah satu tipe dari model pembelajaran kooperatif yang menekankan pada prestasi tim yang diperoleh dari jumlah seluruh skor kemajuan individual setiap anggota tim (Lestari \& Yudhanegara, 2015). Huda (2013) menyatakan bahwa model pembelajaran kooperatif tipe Student Team Achievement 
Perbandingan Hasil Belajar Matematika Antara Siswa yang Pembelajarannya Menggunakan Model Giving Question And Getting Answer dengan Student Teams Achievement Division

Division merupakan salah satu strategi pembelajaran kooperatif yang di dalamnya beberapa kelompok kecil siswa dengan level kemampuan akademik yang berbeda-beda saling bekerja sama untuk menyelesaikan tujuan pembelajaran. Dalam pelaksanaan pembelajaran STAD menggunakan kelompok-kelompok kecil yang beranggotakan empat sampai lima orang, diawali dengan penyampaian materi, kemudian siswa bekerja dalam kelompoknya, setelah itu para siswa mengerjakan soal kuis secara individu, satu sama lain tidak diperbolehkan saling membantu. Hal ini didasarkan pada pendapat Slavin (2005) yang mengatakan bahwa dalam $S T A D$, para siswa dibagi dalam kelompok belajar yang terdiri atas empat orang yang berbeda-beda tingkat kemampuan, jenis kelamin, dan latar belakang etniknya.

STAD terbentuk dari lima komponen utama yang membedakan dengan model pembelajaran kooperatif lainnya. Kelima komponen utama menurut Slavin (2005) secara ringkas adalah sebagai berikut: (1) Presentasi Kelas; materi dalam STAD pertama-tama diperkenalkan dalam presentasi di dalam kelas. Dengan cara ini, para siswa akan menyadari bahwa mereka harus benar-benar memberi perhatian penuh selama presentasi kelas, karena dengan begitu akan membantu mereka mengerjakan kuis dengan baik, dan skor kuis itu akan menentukan skor kelompok mereka. (2) Kelompok; kelompok terdiri dari empat atau lima siswa yang mewakili kemampuan, jenis kelamin, dan ras siswa di kelas itu. Fungsi utama dari kelompok ini adalah memastikan bahwa semua anggota kelompok benar-benar belajar dan dapat menjalani kuis dengan baik. Setelah guru menyampaikan materinya, tim berkumpul untuk mempelajari lembar kegiatan atau materi lainnya. Kelompok memberikan dukungan sesama anggota untuk memperoleh kemajuan akademik, dan kelompok juga menyediakan saling perhatian dan penghargaan yang penting bagi hubungan antar kelompok, rasa harga diri, penerimaan terhadap siswa-siswa yang terpinggirkan. (3) Kuis; setelah presentasi guru dan praktik kelompok, para siswa menjalani kuis individual. Para siswa tidak diperbolehkan untuk saling membantu dalam mengerjakan kuis. Sehingga tiap siswa bertanggung jawab secara individual untuk memahami materinya. (5) Skor Kemajuan Individual; tiap siswa dapat memberikan kontribusi poin yang maksimal kepada kelompoknya dalam sistem penilaian ini, tetapi tidak ada siswa yang dapat melakukan itu tanpa menunjukkan kemajuan yang lebih baik dari sebelumnya. Tiap siswa diberikan skor awal yang diperoleh dari rata-rata prestasi siswa sebelumnya dalam mengerjakan kuis. Selanjutnya siswa akan mengumpulkan poin untuk kelompok mereka berdasarkan tingkat kenaikan skor kuis terhadap skor awal. (6) 
Rekognisi Kelompok; kelompok yang memperoleh skor rata-rata yang mencapai kriteria "Kelompok Super" akan diberikan penghargaan dalam bentuk sertifikat.

Langkah pembelajaran menggunakan STAD adalah sebagai berikut. Guru menyampaikan pelajaran, lalu siswa bekerja dalam tim mereka untuk memastikan bahwa semua anggota kelompok telah menguasai pelajaran. Selanjutnya, semua siswa mengerjakan kuis mengenai materi secara sendiri-sendiri, dimana saat itu mereka tidak diperbolehkan untuk saling membantu.

Adapun kelebihan dan kekurangan model pembelajaran kooperatife tipe Student Team Achievement Division menurut Shoimin (2014) sebagai berikut. Kelebihan model pembelajaran kooperatif tipe Student Team Achievement Division adalah siswa bekerja sama dalam mencapai tujuan dengan menjungjung tinggi norna-norma kelompok, siswa aktif membantu dan memotivasi semangat untuk berhasil bersama, aktif berperan sebagai tutor sebaya untuk lebih meningkatkan keberhasilan kelompok, interaksi antar siswa seiring dengan peningkatan kemampuan mereka dalam berpendapat, meningkatkan kecakapan individu, meningkatkan kecakapan kelompok, tidak besifat kompetitif, tidak memiliki rasa dendam.

Sedangkan kelemahan model pembelajaran kooperatif tipe Student Team Achievement Division adalah kontribusi dari siswa yang berprestasi rendah menjadi kurang, siswa yang berprestasi tinggi akan mengarah kekecewaan karena peran anggota yang pandai lebih dominan, membutuhkan waktu yang lebih lama ntuk siswa sehingga sulit untuk mencapai target kurikulum pembelajaran, membutuhkan waktu yang lebih lama sehingga pada umumnya guru tidak mau menggunakan model pembelajaran kooperatif ini, membutuhkan kemampuan khusus sehingga tidak semua guru dapat melakukan pembelajaran kooperatif, menuntut sifat tertentu dari siswa, misalnya sifat suka bekerja sama.

\section{METODE PENELITIAN}

Penelitian ini adalah penelitian eksperimen, dengan populasi dalam penelitian ini seluruh hasil belajar matematika siswa kelas VII SMP Negeri 1 Lelea Tahun Pelajaran 2017/2018 dengan jumlah 218 siswa yang tersebar dalam 6 kelas, yaitu kelas VII A, VII B, VII C, VII D, VII E, dan VII F. Sampel kelas diambil sebanyak dua kelas dengan menggunakan teknik cluster random sampling, dimana kelas eksperimen I yaitu yang menggunakan model pembelajaran Giving Question and Getting Answer dan kelas eksperimen II yaitu yang menggunakan model pembelajaran Student Teams Achievement 
Perbandingan Hasil Belajar Matematika Antara Siswa yang Pembelajarannya Menggunakan Model Giving Question And Getting Answer dengan Student Teams Achievement Division

Division. Setelah dilakukan pengundian, terpilih kelas VII E dan VII F sebagai sampel. Kelas VII F digunakan untuk kelas eksperimen I yaitu yang menggunakan model pembelajaran Giving Question and Getting Answer dan VII E digunakan untuk kelas eksperimen II yaitu yang menggunakan model pembelajaran Student Teams Achievement Division. Adapun aspek yang akan diukur adalah hasil belajar matematika siswa. Oleh karena itu dalam penelitian ini peneliti menentukan variabel bebas yaitu model pembelajaran Giving Question and Getting Answer dan Student Teams Achievement Divisions, sedangkan untuk variabel terikatnya adalah hasil belajar matematika siswa. Desain penelitian yang digunakan adalah sebagai berikut.

$\mathrm{R}: \mathrm{T}_{1} \mathrm{O}$

$\mathrm{R}: \mathrm{T}_{2} \quad \mathrm{O}$

Keterangan

$\mathrm{R}$ : Randomisasi untuk menentukan sampel

$\mathrm{T}_{1}$ : Perlakuan untuk kelas eksperimen I (menggunakan model pembelajaran Giving Question and Getting Answer)

$\mathrm{T}_{2}$ : Perlakuan untuk kelas eksperimen II (menggunakan model pembelajaran Student Teams Achievement Divisions)

$\mathrm{O}$ : Tes Akhir

\section{HASIL DAN PEMBAHASAN}

Berikut ini akan ditampilkan data hasil observasi dan pengolahan data pada penelitian ini.

Tabel 1. Data Skor Maksimum dan Skor Minimum

\begin{tabular}{ccc}
\hline Skor & Kelas Eksperimen I & Kelas Eksperimen II \\
\hline Maksimum & 31 & 29 \\
Minimum & 2 & 2 \\
Ideal & 31 & 31 \\
\hline
\end{tabular}

Berdasarkan tabel di atas menunjukkan bahwa skor maksimum pada kelas eksperimen I adalah 31 dan skor minimum adalah 2 dari skor ideal 31. Sedangkan skor maksimum pada kelas eksperimen II adalah 29 dan skor minimum adalah 2 dari skor ideal 31. Setelah dilaksanakan pembelajaran dan pengolahan data dari tes akhir (posttest) pada kelas eksperimen I dan eksperimen II diperoleh data tes hasil belajar matematika siswa, data tersebut dapat dilihat pada tabel sebagai berikut. 
Tabel 2. Daftar Distribusi Frekuensi Kelas Eksperimen I

\begin{tabular}{ccc}
\hline Kelas Interval & Batas Kelas & $\boldsymbol{f}_{\boldsymbol{i}}$ \\
\hline $2-6$ & $1,5-6,5$ & 2 \\
$7-11$ & $6,5-11,5$ & 3 \\
$12-16$ & $11,5-16,5$ & 5 \\
$17-21$ & $16,5-21,5$ & 6 \\
$22-26$ & $21,5-26,5$ & 10 \\
$27-31$ & $26,5-31,5$ & 9 \\
\multicolumn{2}{c}{ Jumlah } & $\mathbf{3 5}$ \\
\hline
\end{tabular}

Tabel 3. Daftar Distribusi Frekuensi Kelas Eksperimen II

\begin{tabular}{ccc}
\hline Kelas Interval & Batas Kelas & $\boldsymbol{f}_{\boldsymbol{i}}$ \\
\hline $2-6$ & $1,5-6,5$ & 5 \\
$7-11$ & $6,5-11,5$ & 4 \\
$12-16$ & $11,5-16,5$ & 10 \\
$17-21$ & $16,5-21,5$ & 9 \\
$22-26$ & $21,5-26,5$ & 10 \\
$27-31$ & $26,5-31,5$ & 1 \\
& Jumlah & 39 \\
\hline
\end{tabular}

Pada tabel 2, daftar distribusi frekuensi di atas dapat dilihat bahwa hasil posttest kelas eksperimen I memiliki skor terendah berada pada interval $2-6$ yaitu sebanyak 2 siswa dan skor tertinggi berada pada interval 27 - 31 yaitu sebanyak 9 siswa, kemudian frekuensi terbanyak berada pada interval 22 - 26 yaitu sebanyak 10 siswa. Tabel 3 distribusi frekuensi kelas eksperimen II dapat dilihat bahwa hasil posttest memiliki skor terendah berada pada interval $2-6$ yaitu sebanyak 5 siswa dan skor tertinggi berada pada interval 30 - 31 yaitu sebanyak 1 siswa, kemudian frekuensi terbanyak berada pada interval 12 - 16 dan interval 22 - 26 yaitu sebanyak 10 siswa. Adapun hasil pengolahan data tes akhir (posttest) diperoleh rata-rata, varians dan simpangan baku dari kelas eksperimen I dan kelas eksperimen II, data dapat dilihat pada tabel berikut: 
Perbandingan Hasil Belajar Matematika Antara Siswa yang Pembelajarannya Menggunakan Model Giving Question And Getting Answer dengan Student Teams Achievement Division

Tabel 4. Data Hasil Tes Akhir

\begin{tabular}{lcc}
\hline \multicolumn{1}{c}{ Nilai } & Kelas Eksperimen I & Kelas Eksperimen II \\
\hline Jumlah Siswa $(\mathrm{n})$ & 35 & 39 \\
Rata-rata $(\bar{x})$ & 20,6 & 16,3 \\
Varian $\left(\mathrm{s}^{2}\right)$ & 57,02 & 48,48 \\
Simpangan baku $(\mathrm{s})$ & 7,55 & 6,96 \\
\hline
\end{tabular}

Berdasarkan hasil perhitungan data hasil tes akhir yang ditunjukkan pada tabel 4 di atas, kelas eksperimen I dari 35 siswa diperoleh rata-rata 20,6, varians 57,02. Setelah diperoleh rata-rata dan simpangan baku, langkah selanjutnya yaitu menguji normalitas dan homogenitas data hasil posttest kelas eksperimen I dan kelas eksperimen II. Pada penelitian ini didapat hasil perhitungan uji normalitas sebagai berikut:

Tabel 5. Data Uji Normalitas

\begin{tabular}{cccc}
\hline Kelas & $\chi_{\text {hitung }}^{2}$ & $\chi_{(0,05 ; 3)}^{2}$ & Keterangan \\
\hline Eksperimen 1 & 6,19 & \multirow{2}{*}{7,81} & Normal \\
Eksperimen 2 & 7,22 & & Normal \\
\hline
\end{tabular}

Pada tabel 5 di atas, menunjukkan bahwa pada kelas eksperimen I diperoleh $\chi_{\text {hitung }}^{2}=6,19$ dan $\chi_{\text {tabel }}^{2}=7,81$ sedangkan kelas eksperimen II diperoleh $\chi_{\text {hitung }}^{2}=7,22$ dan $\chi_{\text {tabel }}^{2}=7,81$ dengan taraf signifikan $\alpha=0,05$ dan derajat kebebasan $\mathrm{db}=k-3=6-$ $3=3$. Karena $\chi_{\text {hitung }}^{2}<\chi_{\text {tabel }}^{2}$, maka data hasil posttest kelas eksperimen I dan II berdistribusi normal. Karena kedua data hasil posttest tersebut berdistribusi normal, maka dilanjutkan dengan uji homogenitas dua varians. Uji homogenitas menggunakan varians kelas eksperimen I dan varians kelas eksperimen II. Adapun hasil perhitungan diperoleh data sebagai berikut:

Tabel 6. Data Hasil Uji Homogenitas Dua Varians

\begin{tabular}{ccccc}
\hline Kelas & $\boldsymbol{N}$ & Varians & $\boldsymbol{F}_{\text {hitung }}$ & $\boldsymbol{F}_{\mathbf{0}, \mathbf{0 5}(\mathbf{3 4}, \mathbf{3 8})}$ \\
\hline Eksperimen I & 35 & 57,02 & \multirow{2}{*}{1,18} & 1,74 \\
Eksperimen II & 39 & 48,48 & & \\
\hline
\end{tabular}

Berdasarkan data uji homogentas dua varians dengan taraf signifikan $\alpha=0,05$ serta $d k_{1}=34$ dan $d k_{2}=38$, diperoleh $F_{\text {hitung }}=1,18$ dan $\mathrm{F}_{\text {tabel }}=1,74$. Karena $\mathrm{F}_{\text {hitung }}<\mathrm{F}_{\text {tabel}}$, maka berdasarkan kriteria uji homogenitas dapat disimpulkan data hasil tes akhir dari kedua kelompok dikatakan homogen. Berdasarkan perhitungan uji normalitas dan homogenitas terhadap data tes akhir, ternyata data tes akhir kelas eksperimen I dan kelas eksperimen II berdistribusi normal dan bersifat homogen, maka alternatif selanjutnya dilakukan uji beda dua rerata yaitu menggunakan uji-t. Hal ini bertujuan untuk mengetahui hasil belajar matematika siswa manakah yang lebih baik antara yang menggunakan model 
pembelajaran Giving Question and Getting Answer dengan Student Teams Achievement Division. Hipotesis yang diajukan adalah hasil belajar matematika siswa yang pembelajarannya menggunakan model Giving Question and Getting Answer lebih baik dari siswa yang pembelajarannya menggunakan model Student Teams Achievement Division. Hipotesis statistik yang diajukan adalah sebagai berikut:

$H_{0}: \mu_{1} \leq \mu_{2}$

$H_{a}: \mu_{1}>\mu_{2}$

Keterangan :

$\mu_{1}$ : Skor rata-rata siswa yang pembelajarannya menggunakan model Giving Question and Getting Answer.

$\mu_{2}$ : Skor rata-rata siswa yang pembelajarannya menggunakan model Student Teams Achievement Division.

Tabel 7. Data Hasil Uji Beda Dua Rerata

\begin{tabular}{cccccc}
\hline Kelas & Rerata & Varians & $\boldsymbol{s}_{\text {gab }}$ & $\boldsymbol{t}_{\text {hitung }}$ & $\boldsymbol{t}_{\text {tabel }}$ \\
\hline Eksperimen I & 20,6 & 57,02 & \multirow{2}{*}{7,25} & 2,40 & \multirow{2}{*}{1,99} \\
Eksperimen II & 16,3 & 48,48 & & & \\
\hline
\end{tabular}

Berdasarkan tabel 7 dengan taraf signifikan 0,05 dan derajat kebebasan $(d k)=72$ diperoleh $t_{\text {hitung }}=2,40$ dan $t_{(0,05)(72)}=1,99$. Hal ini menunjukkan bahwa $t_{\text {hitung }}>t_{\text {tabel }}$. Maka berdasarkan kriteria pengujian hipotesis dapat disimpulkan bahwa $\mathrm{H}_{0}$ ditolak, artinya hasil belajar matematika siswa yang menggunakan model pembelajaran Giving Question and Getting Answer lebih baik dari siswa yang menggunakan model Student Teams Achievement Division.

\section{KESIMPULAN}

Dari perhitungan uji beda dua rata-rata dengan Uji-t, hasil tes akhir diperoleh nilai $t_{\text {hitung }}=2,40$ dan $t_{\text {tabel }}=1,99$. Dari kriteria pengujian hipotesis, karena $t_{\text {hitung }}>t_{\text {tabel }}$, maka $H_{0}$ ditolak. Hal ini menunjukkan adanya perbedaan hasil belajar matematika antara siswa yang menggunakan model pembelajaran Giving Question and Getting Answer dengan Student Teams Achievement Division Rata-rata kelas yang menggunakan model pembelajaran Giving Question and Getting Answer yaitu 20,6, sedangkan rata-rata kelas yang menggunakan model pembelajaran Student Teams Achievement Division yaitu 16,3. Berdasarkan hasil uji hipotesis dengan taraf signifikan $a=0,05$, dapat disimpulkan bahwa hasil belajar matematika siswa yang menggunakan model pembelajaran Giving Question and Getting Answer lebih baik dari Student Teams Achievement Division. 
Perbandingan Hasil Belajar Matematika Antara Siswa yang Pembelajarannya Menggunakan Model Giving Question And Getting Answer dengan Student Teams Achievement Division

Saran peneliti dalm penelitian ini kepada peneliti lain adalah dalam proses belajar matematika di sekolah model pembelajaran kooperatif tipe Giving Question and Getting Answer dan Student Teams Achievement Division dapat dijadikan alternatif dalam pembelajaran di kelas. Diharapkan seorang guru agar memperhatikan lagi pengelompokan siswa, agar diperoleh kelompok yang sesuai, baik jumlah siswa maupun kemampuannya, segingga siswa yang prestasinya tinggi dapat terbagi di setiap kelompok untuk membantu siswa yang lainnya, dengan harapan dapat meningkatkan hasil belajar siswa.

\section{DAFTAR PUSTAKA}

Dimyati \& Mudjiono. (2006). Belajar dan Pembelajaran. Jakarta: PT Rineka Cipta.

Hamdani. (2011). Strategi Belajar Mengajar. Bandung: CV Pustaka Setia.

Heriawan, A., Darmajari, \& Senjaya, A. (2012). Metodologi Pembelajaran: Kajian Teoritis, Model, Pendekatan, Strategi, Metode, dan Teknik Pembelajaran. Banten: Perum Bumi Baros Chasanah.

Huda, M. (2013). Model-model Pengajaran dan Pembelajaran. Yogyakarta: Pustaka Pelajar.

Jannah, R. (2011). Membuat Anak Cinta Matematika dan Eksak Lainnya. Yogyakarta: DIVA Press.

Lestari, K. E., \& Yudhanegara, M. R. (2015). Penelitian Pendidikan Matematika. Bandung: Refika Aditama.

Rohman, M., \& Amri, S. (2013). Strategi dan Desain Pengembangan Sistem Pembelajaran. Jakarta: Prestasi Pustakaraya.

Ruseffendi, E. T. (2006). Pengantar Kepada Membantu Guru Mengembangkan Kompetensinya dalam Pengajaran Matematika untuk Meningkatkan CBSA. Bandung: Tarsito.

Rusman. (2013). Model-model Pembelajaran Mengembangkan Profesionalisme Guru. Jakarta: Raja Grafindo Persada.

Slavin, R. E. (2005). Cooperative Learning, Teori, Riset dan Praktik. Bandung: Nusa Media.

Shoimin, A. (2014). 68 Model Pembelajaran Inovatif dalam Kurikulum 2013. Rembang: Ar-Ruzz Media.

Sudjana, N. (2011). Dasar-Dasar Proses Belajar Mengajar. Bandung: Sinar Baru Algensindo.

Suprijono, A. (2009). Cooperative Learning. Surabaya: Pustaka Pelajar.

. (2015). Cooperative Learning Teori dan Aplikasi PAIKEM. Yogyakarta: Pustaka Pelajar.

Uno, H. B. (2009). Mengelola Kecerdasan Dalam Pembelajaran. Jakarta: PT Bumi Aksara. 